VERSITA
SINGIDUNUM

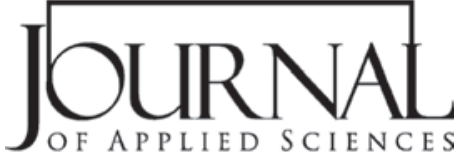

SJAS 2014, 11 (1): 53-66

ISSN 2217-8090

UDK: 336.763 .3

DOI: $10.5937 /$ sjas11-4766

Original paper/Originalni naučni rad

\title{
DURATION AND CONVEXITY OF BONDS
}

\author{
Slobodan Čerović1 ${ }^{1,}$, Marina Pepić ${ }^{2}$, Stanislav Čerović ${ }^{3}$, Nevena Čerović ${ }^{4}$ \\ ${ }^{1}$ Singidunum University, Department of Tourism and Hospitality, \\ 32 Danijelova Street, Belgrade, Serbia \\ ${ }^{2}$ National Bank of Serbia \\ 12 Kralja Petra Street, Belgrade, Serbia \\ ${ }^{3}$ Singidunum University, Master's graduate student \\ 32 Danijelova Street, Belgrade, Serbia \\ ${ }^{4}$ University of Belgrade, Faculty of Economics, Master's student \\ 6 Kamenička Street, Belgrade, Serbia
}

\begin{abstract}
:
The wide impact that interest rate changes have on business performance, the fact that all market participants are, more or less, exposed to interest rate risk, as well as high volatility in interest rates in recent years, make interest rate risk one of the most significant risks.

It is impossible to neutralize interest rate risk completely, but it is desirable to reduce it to a minimum. In order to effectively manage it, interest rate risk must first be identified and measured. This paper aims to show the two methods of measuring the interest rate risk - duration and convexity.

The concept of duration is a good indicator of changes in the price of bonds but only for small changes in the interest rates. In case of major changes, the duration gives overestimated/underestimated approximation of the bond price, because bond price-yield relationship is not linear. Therefore, when measuring interest rate risk, convexity of bonds must be taken into account. Modified duration and convexity taken together provide the best approximation of the sensitivity of bond prices to changes in interest rates.
\end{abstract}

\author{
Key words: \\ Macaulay, \\ modified, \\ effective, \\ empirical and dollar duration, \\ duration of a portfolio, \\ modified and effective convexity, \\ convexity of a portfolio.
}

\section{INTRODUCTION}

The wide impact that interest rate changes have on business performance, the fact that all market participants are, to a higher or lesser degree, exposed to interest rate risk (regarding the value and structure of balance and off-balance positions sensitive to interest rate changes, volatility in interest rate, and duration of exposure to risk), as well as high volatility in interest rates during the recent years, make interest rate risk one of the most significant risks. Therefore, it is of the utmost importance to manage this kind of risk adequately.

It is difficult to completely neutralize interest rate risk, however, in regard to the great impact that in- terest rate changes have on business performance, it is necessary to reduce it to a minimum. In order to manage it effectively, exposure to interest rate risk must first be identified and measured.

This paper represents an attempt to clarify the two basic methods of measuring interest rate risk - duration and convexity, and to show their advantages, as well as drawbacks. The third method of measuring interest rate risk - value at risk $(\mathrm{VaR})$ is not the subject of this paper.

The paper will first explain the notion and characteristics of the concept of duration, then the types of duration, and finally the advantages and limitations of this concept. After that the concept of convexity will be discussed, i.e. characteristics, types, advantages 
and limitations of this concept. Application of the concepts of duration and convexity to portfolio will be clarified as well.

\section{DURATION}

A bond is an instrument of indebtedness that obliges the bond issuer (borrower) to repay the lender (creditor) the borrowed assets plus the interest within a certain period of time (Fabozzi, 2000, p. 1). There are coupon and zero-coupon bonds. With coupon bonds a periodic interest (coupon) payment is present. With zero-coupon bonds yield is the difference between the purchase price of a bond and its face value, i.e. its selling price in case it is sold before maturity.

The nominal yield is bond yield based on coupons (Šoškić and Živković, 2006, p. 236). Since coupon rate is fixed and not sensitive to market changes, it is not of importance to the investors when making a decision whether a bond investment is worthwhile. Therefore, current yield and yield to maturity are most often used as yield indicators.

Current yield is a quotient of the coupon yield for a certain period and the purchase price (Mishkin and Eakins, 2005, p. 258). Current yield is greater than nominal (coupon) yield when the price of a bond is less than nominal, and vice versa, current yield is less than nominal when the price of a bond is greater than nominal. Current yield is sensitive to changes in bond price and therefore a good indicator of whether a bond investment is worthwhile.

When reaching long-term decisions yield to maturity of a bond is used for yield calculation. The yield to maturity is the discount rate at which the value of current cash flows from the bond is equal to the price of the bond (Šoškić and Živković, 2006, p. 237). At the moment of the flotation of a bond yield to maturity is equal to the market interest rate.

If the market interest rate changes during a period of time, the bond price will change as well. The price of a coupon bond is equal to (Šoškić and Živković, 2006, p. 259):

$$
\boldsymbol{P}=\sum_{t=1}^{n} \frac{\mathbf{C}_{t}}{(1+\mathrm{i})^{\mathrm{t}}}+\frac{\mathbf{M}}{(1+\mathrm{i})^{\mathbf{n}}}
$$

where $\mathrm{P}$ is - price of a bond, $\mathrm{C}$ - coupon value, $\mathrm{M}$ - nominal bond value, $\mathrm{n}$ - number of years to maturity, $\mathrm{i}$ - required yield or market interest rate.
The required yield is a yield generated by market for bonds with fixed maturity date and fixed level of risk.

In case of multiple annual coupon payments, bond price will be (Šoškić and Živković, 2006, p. 259):

$$
P=\sum_{\mathrm{t}=1}^{\mathrm{n}} \frac{\frac{\mathrm{C}_{\mathrm{t}}}{\mathrm{m}}}{\left(1+\frac{\mathrm{i}}{\mathrm{m}}\right)^{\mathrm{t}}}+\frac{\frac{\mathrm{M}}{\mathrm{m}}}{\left(1+\frac{\mathrm{i}}{\mathrm{m}}\right)^{\mathrm{mn}}}
$$

where $\mathrm{m}$ is - number of coupon payments in a year.

With changes in market interest rates the required yield for the bond changes as well. When the coupon rate is equal to the required yield, the bond price will be equal to the principal. When the coupon rate is greater than the required yield, the bond price will be greater than the nominal value and this bond will be selling at a premium. When the coupon rate is less than the required yield, the bond price will be less than the nominal value and this bond will be selling at a discount.

Regarding zero-coupon bonds, as we said before, yield is the difference between purchase bond price and its nominal value, i.e. selling price if sold prior to maturity. The zero-coupon bond price is equal to the present value of the sum received on the maturity date and it is calculated according to the following formula (Šoškić and Živković, 2006, p. 260):

$$
P=\frac{M}{(1+i)^{n}}
$$

Not only is the overall cash flow that bond rejects important for investment decision, but also the period in which it happens. Maturity of the bond gives information only on the date of the final payment, but not on the size and date of coupon payments prior to the last payment of coupon and principal. The longer the period to maturity and the higher the coupon rate and yield to maturity, the more important coupon payments become when compared to payments upon the maturity of the bond. Maturity of the bond, therefore, is not an adequate indicator of the time required to make investment in bonds worthwhile. Thus, the concept of bond duration has been developed.

Duration is a measure of interest rate risk of bonds and it is used to determine the average period of ma- 
turity of the bond. The concept of duration measures price sensitivity of bonds or bond portfolios to the changes in interest rates (Choudhry, 2005, p. 32). Bonds with longer duration have higher changes in price than bonds with shorter duration, and that represents a greater risk.

Bond duration is an approximation of the percentage change in bond price regarding the change in interest rate of 100 basis points. It is calculated according to the formula (Fabozzi, 1996, p. 49):

$$
D=\frac{P_{-}+P_{+}}{2 P(\Delta i)}
$$

where $\mathrm{D}$ is - duration of bond, $\mathrm{P}$ - initial bond price, $\Delta \mathrm{i}$ - change in yield, $\mathrm{P}_{+}$- estimated bond value in case of yield rise for $\Delta \mathrm{i}, \mathrm{P}$ - estimated bond value in case of yield drop for $\Delta \mathrm{i}$. Values for $\mathrm{P}_{+}$and $\mathrm{P}$ are obtained using the model for bond valuation. It is important to stress that the parallel shift of the yield curve is expected, that is, the yield change $\Delta \mathrm{i}$ is the same for all maturities.

Let's suppose that the initial price of $9 \% 20$ years bond (Fabozzi, 1996, p. 49) is 134.6722, and that the current yield is $6 \%$. If the yield, for instance, is decreased by 20 basis points (from 6\% to 5.8\%), the bond price will increase to 137.5888 . If the yield is increased by 20 basis points (from 6\% to 6.2\%), the bond prices will fall to 131.8439 . Duration of the bonds in this case, according to the formula (4), will be 10.66 . This means that the bond price would change by approximately $10.66 \%$ for a 100 basis points yield shift.

Approximate percentage change in bond price for given market rate change and given duration is calculated in the following way (Fabozzi, 2007, p. 170):

$$
\begin{aligned}
& \text { Approximate percentage } \\
& \text { change in price }
\end{aligned}=-D^{*}(\Delta \mathrm{i}) * 100
$$

Negative symbol in front of duration $\mathrm{D}$ indicates that price and yield stand in inverse relation. In the above example (9\% 20-year bond with duration of 10.66 and price of 134.6722) approximate percentage change in price for a 10 basis points yield change $(\Delta \mathrm{i}=0.001)$ would be: $-10.66^{\star} 0,001^{\star} 100=-1.066 \%$. So, if yield rose by 10 basis points, bond price would decline by $1,066 \%$. Approximation of price change is a fairly reliable indicator for lesser changes in market rates. Nevertheless, for greater changes in interest rates, the results are not that good. Namely, because of the convexity of the price/yield curve (to be elaborated upon further on), estimated change in bond value for greater rate changes will result in underestimated/overestimated bond value.

\section{Duration and yield to maturity}

Relation between yield to maturity and duration is shown by the following formula (La Grandwille, 2001, p. 81):

$$
\frac{d D}{d i}=-(1+i)^{-1} S
$$

where $S$ is dispersion measured by a variance of the bond payment number. Because of '-' symbol dD/ $d i$ will always be negative, which means that there is an inverse relation between duration and yield, i.e. duration drops with the rise of yield to maturity and vice versa. This of course applies to coupon bonds. With zero-coupon bonds duration is always equal to maturity because the whole sum is paid upon maturity (or upon possible selling of the bond beforehand).

\section{Macaulay duration}

The concept of duration has been present in analysis and portfolio management for several decades and a few modifications have been developed through time. The first concept originated some 70 years ago and it was named Macaulay duration after its author - Frederick Macaulay. He showed that the number of years to bond maturity is not adequate for measuring time component of the debt, and that the bond duration is a far better measure since it takes into account the payment of principal in the end, as well as the coupon payments. The Macaulay duration is a weighted arithmetic mean of cash flow maturity which the bond rejects, where participation of the current value of cash flows in the bond price is used as weight, i.e. weight for every cash flow is calculated by dividing the current value of cash flow by the bond price, in other words, Macaulay duration is calculated using the following formula (Choudhry, 2005, p. 33): 


$$
D=\frac{\sum_{t=1}^{n} \frac{t C_{t}}{(1+i)^{t}}}{P}
$$

$$
D=\frac{\sum_{t=1}^{n} \frac{t C_{t}}{(1+i)^{t}}}{P}=\frac{\sum_{t=1}^{n} \frac{t C_{t}}{(1+i)^{t}}}{\sum_{t=1}^{n} \frac{C_{t}}{(1+i)^{t}}+\frac{M}{(1+i)^{n}}}
$$

where $\mathrm{P}$ is - bond price, $\mathrm{t}$ - period during which payment of coupon or principal occurs, $C_{t}$ - value of cash flow in period $\mathrm{t}, \mathrm{i}$ - yield to maturity of bond.

This equation's numerator contains the current value of all cash flows valuated according to the period of payment maturity, while denominator contains the bond price after the model of current value. Thus by applying the formula (1) we get the following formula:

\begin{tabular}{ccc} 
& Bond A & Bond B \\
\hline Nominal value & $\$ 1000$ & $\$ 1000$ \\
Maturity & 10 years & 10 years \\
Coupon rate & $4 \%$ & $8 \%$ \\
\hline
\end{tabular}

Bond $\mathrm{A}$

\begin{tabular}{cccccc}
\hline Year & Cashflow & PV at $8 \%$ & PV of yheflow & PV as \% of the price & $1 * 5$ \\
$(1)$ & $(2)$ & $(3)$ & $(4)$ & $(5)$ & $(6)$ \\
1 & 40 & 0.9259 & 37.04 & 0.0506 & 0.0506 \\
2 & 40 & 0.8573 & 34.29 & 0.0469 & 0.0938 \\
3 & 40 & 0.7938 & 31.75 & 0.0434 & 0.1302 \\
4 & 40 & 0.7350 & 29.40 & 0.0402 & 0.1608 \\
5 & 40 & 0.6806 & 27.22 & 0.0372 & 0.1860 \\
6 & 40 & 0.6302 & 25.21 & 0.0345 & 0.2070 \\
7 & 40 & 0.5835 & 23.34 & 0.0319 & 0.2233 \\
8 & 40 & 0.5403 & 21.61 & 0.0295 & 0.2360 \\
9 & 40 & 0.5002 & 20.01 & 0.0274 & 0.2466 \\
10 & 1040 & 0.4632 & 481.73 & 0.6585 & 6.5850 \\
\hline
\end{tabular}

\begin{tabular}{cccccc}
1 & \multicolumn{5}{c}{ Bond B } \\
2 & 80 & 0.9259 & 74.07 & 0.0741 & 0.0741 \\
3 & 80 & 0.8573 & 68.59 & 0.0686 & 0.1372 \\
4 & 80 & 0.7938 & 63.50 & 0.0635 & 0.1906 \\
5 & 80 & 0.7350 & 58.80 & 0.0588 & 0.1906 \\
6 & 80 & 0.6806 & 54.44 & 0.0544 & 0.2720 \\
7 & 80 & 0.6302 & 50.42 & 0.0504 & 0.3024 \\
8 & 80 & 0.5835 & 46.68 & 0.0467 & 0.3269 \\
9 & 80 & 0.5403 & 43.22 & 0.0432 & 0.3456 \\
10 & 80 & 0.5002 & 40.02 & 0.0400 & 0.3600 \\
Total & 1080 & 0.4632 & 500.26 & 0.5003 & 5.0030 \\
Duration $=7.25$ years & & 1000.00 & 1.0000 & 7.2470 \\
\hline
\end{tabular}

Source: Reilly and Brown (2003, p. 769) 
There are some characteristics of Macaulay duration. Firstly, Macaulay duration of a coupon bond is always less than maturity, since the concept of duration takes coupon payments into consideration; secondly, there is an inverse relation between how high the coupon rate is and the duration. Bonds with higher coupon payments have shorter duration because more cash flows arrive beforehand as coupon payments. Zero-coupon, i.e. strictly discount bonds have duration that equals maturity; thirdly, there is a positive relation between maturity and Macauley duration, where the duration rises according to decremental rate at the rise in maturity. This indicates that the bond with a longer maturity will almost always have greater duration. The relation is not direct because as the maturity grows, the present value of principal drops; fourthly, there is an inverse relation between yield to maturity and duration; fifthly, callability of a bond can influence the duration significantly, since the callability of bond changes the cash flow of bond and thus the duration as well.

\section{Modified duration}

Modified duration shows approximate percentage price change of a bond for the change in yield of 100 basis points (Choudhry, 2005, p. 37). The assumption is that the cash flow stays unchanged with the change in yield.

Modified duration is calculated in the following way (Fabozzi, 1996, p. 53):

$$
\begin{aligned}
& \text { Modified } \\
& \text { duration }
\end{aligned}=\frac{\text { Macauley }}{\text { duration }}
$$

For example, a bond with Macaulay duration of 10 years, yield to maturity of $8 \%$ and semi-annual coupon payments would have the following modified duration:

$$
D=10 /\left(1+\frac{0.08}{2}\right)=10 / 1.04=9.62
$$

The alteration in price of non-callable bonds, for small yield changes, will be changing in proportion to modified duration. More precisely, predicted percentage of bond price change is equal to yield change multiplied by modified duration (Reilly and Brown, 2003, p. 771):

$$
\frac{\Delta P}{P} * 100=-D_{\bmod } * \Delta i
$$

where $\Delta \mathrm{P}$ is - bond price change, $\mathrm{P}$ - initial bond price, $-\mathrm{D}_{\text {mod }}-$ modified duration, $\Delta \mathrm{i}-$ yield change in basis points.

If we want to estimate the price change of a bond with Macaulay duration of 10 years, yield to maturity of $8 \%$ and semi-annual coupon payments for a 50 basis points change in yield (say, from $10.0 \%$ to $9.5 \%)$, the first step would be to calculate the modified duration, and than projected percentage change in bond price:

$$
\begin{aligned}
& D_{\text {mod }}=10 /(1+0.8 / 2)=9.62 \\
& \% \Delta P=-9.62 *(-0.50)=4.81
\end{aligned}
$$

Thus, the bond price will change by approximately $4.81 \%$ as a result of a 50 basis points yield decrease. If the initial price was $\$ 1000$, after the change in yield the price would be 1048.1 (\$1000* 1.0481).

Starting with the formula (10) we can reach formula for new price of a bond:

$$
\text { New price }=\left[\left(D * \frac{\Delta i}{100}\right) / 100+1\right] * P
$$

Modified duration is always negative for noncallable bonds because of the inverse relation between yield change and bond price. We should, however, bear in mind that this takes into account only the approximation of price change, and that valid results for price change can only be obtained for very small changes in yield.

The Macauley and modified duration are quite significant when considering volatility and interest sensitivity of a bond. However, it is very important to refer to significant limitations of these two concepts once more.

Firstly, Macauley and modified duration give a good approximation only for small changes in yield. Two bonds with the same duration can have different change in price for major yield changes, depending on bond convexity. 
Secondly, it is quite difficult to assess interest sensitivity of a bond portfolio in case of nonparallel shift of the yield curve. Duration of portfolio is calculated as weighted average of duration of the bonds from portfolio. Problem is non-existent as long as the yield curve shift is parallel. However, if the yield curve shift is not parallel, the question is which change in yield to take - short-termed, medium-termed or longtermed yield curve. Two portfolios that shared the same duration in the beginning can have different durations in the end, depending on how the yield curve shifted.

The third drawback is related to the fact that these two concepts assume a bond without embedded option. The duration of a bond with embedded option would be somewhere between duration to maturity and duration to the first call, and the specific value depends on relation between current market rates and coupon rate.

In order to overcome these drawbacks a new way of assessing the duration of a bond which takes into account the aforementioned cases has been developed.

\section{Effective duration}

Effective duration is a direct measure of the interest sensitivity of a bond in cases where it is possible to use valuation models for establishing price. The advantage of this concept is the possibility for duration to be longer than maturity, or to be negative, which can also be applied to the bonds with embedded option. Namely, effective convexity allows for the cash flow of a bond to be liable to change due to yield change when the bond with embedded option is in question.

With small changes in market rates, and with bonds without embedded option, effective duration is equal to modified duration for small yield changes (Reilly and Brown, 2003, p. 783):

$$
D_{\text {eff }}=\frac{P_{-}+P_{+}}{2 P S}
$$

where $\mathrm{P}$ is - estimated bond price after drop in interest rate, $\mathrm{P}_{+}$- estimated bond price after rise of interest rates, $\mathrm{P}$ - current price of a bond, i.e. the price before yield change, and $S$ - expected shift in futures structure. The formula assumes small changes in yield
(10 basis points) up or down and use of a model to determine expected market prices of a bond $\left(\mathrm{P}_{+}\right.$and P) for new yields.

Suppose that bond with the following characteristics does not have an embedded option (Reilly and Brown, 2003, pp. 783-784):

\begin{tabular}{lc}
\hline Nominal value & $\$ 1000$ \\
\hline Coupon rate & $6 \%$ \\
\hline Maturity & 8 years \\
\hline The initial yield to maturity & $6 \%$ \\
\hline The initial price & 100 \\
\hline
\end{tabular}

and that the change in the yield is 10 basis points. Then you have the following: $\mathrm{P}$ (for 5.90\%) would be equal to 100.4276 , and $\mathrm{P}_{+}$(for $6.10 \%$ ) 99.5746, while the effective duration would be:

$$
D_{e f f}=\frac{P_{-}-P_{+}}{2 P S}=\frac{100.4276-99.5746}{2 * 100 * 0.001}=4.26
$$

As it is a bond without option, effective duration will be the same as modified.

$$
D_{\text {mod }}=4.39 /(1+0.06 / 2)=4.39 / 1.03=4.26
$$

However, in the case of callable bond, the situation would be different. Let us say that the bond is callable after 3 years at 106 . The use of the model to determine the bond price for $4 \%$ yield ( $\mathrm{P}$ would be 108.2408) would give the following: for yield 3.90\% (decrease of 10 basis points) $\mathrm{P}$ would be 108.5563 , and for $4.10 \% \mathrm{P}_{+} 107.9232$, while the effective duration would be:

$$
D_{\text {eff }}=\frac{P_{-}-P_{+}}{2 P S}=\frac{108.5563-107.9232}{2 * 108.2408 * 0.001}=2.92
$$

As expected, regarding that the value of the callable bond rises with the drop in yield, duration is shorter than the duration of the bond without embedded option. The effective duration of the callable bond for higher yields will be equal to the duration of the bond without embedded option because the value of the option is close to zero. 
In order to better understand the influence of callability on the duration of bonds, it is necessary to consider factors which determine the price of the bond with embedded option. Call or put option can be embedded on the bond. The call option gives certain rights to the issuer, and the put option to the buyer (holder) of the bond. Callable bond is a combination of a non-callable bond and call option which ensures the certain right to the issuer, and thus has a negative influence on the price. Hence, purchasing a callable bond is the same as purchasing a non-callable bond + selling a call option, and the price is equal (Reilly and Brown, 2003, p. 778):

$\underset{\text { ballable }}{\text { bond price }}=\begin{gathered}\text { non-callable } \\ \text { bond price }\end{gathered}-\begin{gathered}\text { call op- } \\ \text { tion price }\end{gathered}$

Everything that increases the value of call option will decrease the value of the callable bond. When interest rates drop, the non-callable bond price increases, as well as and the price of call option, so the change in the callable bond price will depend on which of these two prices changes faster. If, due to drop in interest rates, the value of call option rises faster than the value of non-callable bond, the value of callable bond will drop (negative duration), which is opposite to the conventionally inverse relation between change in yield and bond price. The effective duration can be negative, contrary to the modified duration.

The duration of the callable bond will be somewhere between the duration to maturity and the duration to the first call, depending on the probability of the issuer utilizing his right from the option and calling the bond before maturity date, which in its turn depends on the level of interest rates in relation to coupon rates. The duration of a bond with embedded option is equal to (Reilly and Brown, 2003, p. 780):

$\begin{array}{ccc}\begin{array}{c}\text { Duration of } \\ \text { bond with } \\ \text { embedded } \\ \text { option }\end{array} & \begin{array}{c}\text { duration of } \\ \text { non-callable } \\ \text { bond }\end{array} & -\begin{array}{c}\text { duration } \\ \text { of call } \\ \text { option }\end{array}\end{array}$

At a high level of interest rates, the change in yield will not have great influence on the price of option. As a result, the duration of option will be close to zero, and the duration of callable bond will be nearly equal to the duration of non-callable bond and other way round. With options that are extremely sensi- tive to shift in interest rates (e.g. mortgage ones), the duration is negative, that is, their price drops when interest rates drop.

When it comes to the bonds with the possibility of a buyer charging them before maturity date, i.e. to the bonds with put option, there is positive influence of option on the bond value which rises with the rise in interest rates. This means that when interest rates rise, the price of this kind of bond does not drop as much as the price of the bond without embedded option, but when the rates drop, the price of the bond with put option shifts similar to the price of bond without embedded option (since the option value is close to zero). Therefore, the value of the bond with possibility of being charged beforehand is equal to the value of the bond without embedded option augmented by the put option value.

The effective duration, as we have already mentioned, can be longer than maturity and that is the case with some kinds of assets where the interest sensitivity is extremely high. The effective duration assumes the appliance of interest models and models for determining bond prices that take into account the change in cash flows with the change in yield. Be that as it may, the problem occurs while measuring interest sensitivity for assets where it is impossible to predict the change in price based on change in yield. For example, the influence of interest rates change on stocks can be overcome by influence of rate of growth which cannot be predicted. The concept of empirical duration has been developed with the aim of securing some approximation of interest sensitivity of a bond even under these conditions.

\section{Empirical duration}

Empirical duration represents the real percentage change in price of assets for the given change in yield during a certain period of time (Reilly and Brown, 2003, p. 788):

$$
\% \Delta P=-D_{\bmod } * \Delta i
$$

Where $\Delta \mathrm{i}$ is change of interest rate in basis points divided by 100 .

We start from the assumption that $\mathrm{D}_{\text {mod }}$ and $\Delta \mathrm{i}$ are already known. The equation can also be written in the following way: 


$$
-D_{\text {mod }}=\frac{\% \Delta P}{\Delta i}
$$

However, $\mathrm{D}_{\text {mod }}$ is not a modified duration any more, but the empirical one, i.e.:

$$
D_{e m p}=-\frac{\% \Delta P}{\Delta i}
$$

For example, if the yield is decreased by 150 basis points and the bond price is increased by $10 \%$, the empirical duration would be:

$$
D_{\text {emp }}=-\frac{\% \Delta P}{\Delta i}=-\frac{10}{-150 / 100}=6.67
$$

Thus, we can say that the empirical duration is an approximation for percentage change in price when the interest rate changes for 100 basis points.

\section{Dollar duration}

If two bonds have the same modified duration, it does not mean that the change in price for the absolute sum of these bonds will be the same. Two bonds, $A$ and $B$, have the same duration of 10 , but the price of bond $A$ is 100 and of bond $B$ is 80 . If yield is changed by 100 basis points, the absolute change in the price of the bond A will be $\$ 10\left(10^{\star} 100^{\star} 0.01\right)$, and for the bonds $\mathrm{B} \$ 8\left(10^{\star} 0.01^{\star} 80\right)$. The absolute change in bond price due to change in yield is calculated according to the following formula (Fabozzi, 1996, p. 50):

Price change $=-D_{\text {mod }}^{*}$ price in $\$ *$ change of rate

Change in bond price obtained from this equation is called dollar duration. Accordingly, the dollar duration shows the absolute change in bond price due to rate change of 100 basis points.

\section{PORTFOLIO DURATION}

There are two ways for calculating portfolio duration. The first one is a result of weighted average du- ration, according to the following formula (Fabozzi, 1996, p. 54):

$$
W_{1} D_{1}+W_{2} D_{2}+W_{3} D_{3}+\ldots+W_{n} D_{n}
$$

Where $\mathrm{w}_{1,2 \ldots \mathrm{n}}$ are weights which stand for a share of market value of a bond for a total value of portfolio $\mathrm{w}_{1 . . .} \mathrm{w}_{\mathrm{n}}$, and $n$ is number of bonds in portfolio.

Another way of calculating portfolio duration is by using the absolute change in price of every bond in portfolio. The percentage price change is obtained by dividing the total change in price by the initial market value of portfolio.

The portfolio duration cannot be longer than the longest duration of a single bond in portfolio, but it also cannot be shorter than the shortest duration of a single bond in portfolio. Therefore, the duration of portfolio is always between the shortest and the longest duration of individual bonds in portfolio.

\section{Advantages and drawbacks of the concept of duration}

The concept of duration is a good indicator of percentage change in price only for small changes in yield. With large changes in yield, the duration is a wrong measure since it shows overestimated/ underestimated approximation of the price change in relation to real change in bond price. For small changes in yield, the percentage change in price is almost the same, regardless of the rise or drop in yield, while for the great changes in yield the percentage change in price is not the same when it comes to rise or drop in yield. Chart 1 displays the relation between bond price and yield. Duration is linearization of convexity.

If change in yield occurs, the tangent helps us estimate a new price. If a vertical line is drawn anywhere on the horizontal line of yield, the difference between $\mathrm{X}$-axis and tangent line shows approximate change in price for the initial yield $y^{\star}$. For small changes in yield the tangent is close to real priceyield relation. However, the more the current yield changes in relation to the initial yield, the greater is the duration based price approximation error. The reason for this is the convex shape of the price-yield curve. The greater the convexity, the less accurate the use of concept of duration only will be. 


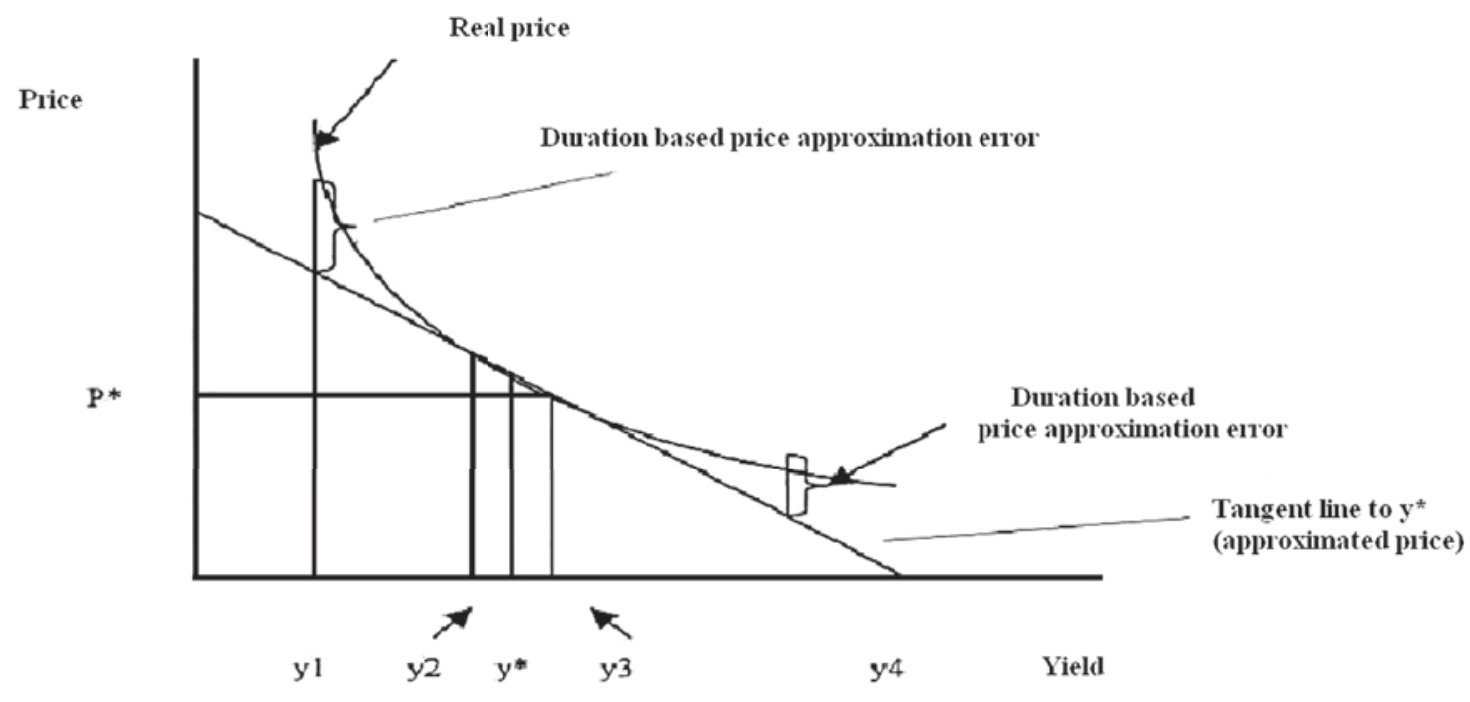

Chart 1: Change in price

Source: Fabozzi (2007, p. 173)

\section{CONVEXITY}

\section{Concept and characteristics}

Bearing in mind the price-yield relation, modified duration may be defined as the percentage change in price in response to nominal change in yield (Reilly and Brown, 2003, p. 774):

$$
D_{\text {mod }}=\frac{d P / d i}{P}
$$

where $\mathrm{dP} / \mathrm{di}$ is the tangent to the price-yield curve for the given yield rate.

As we can see from Chart 1 , for small changes in yield the tangent provides a good reflection of the changes in bond price. However, for major changes in yield, the tangent reveals a lower bond price than the price-yield curve. Such erroneous estimation occurs because modified duration is a linear approximation of a non-linear price-yield relation. Consequently, all the approximations based exclusively on modified duration underestimate the increase in price caused by a decrease in yield and overestimate the decrease in price that follows an increase in yield. Chart 1 also shows that price changes are not symmetrical when it comes to yield increasing and decreasing. The error in estimation is greater when interest rates drop than when they rise, for when yield drops, prices rise at an incremental rate, whereas when yield rises, prices drop at a decremental rate. So, the price-yield curve is not a straight but a curved line. Convexity is a measure of the curvature of the price-yield curve (Hull, 2009, p. 90).

\section{Modified convexity}

Since modified duration is a measure of the curve slope for the given yield, convexity indicates a change in duration. Mathematically, convexity is the second derivative of the price-yield function per yield divided by price, that is, the percentage change of $\mathrm{dP} / \mathrm{di}$ for the given change in yield (Reilly and Brown, 2003, p. 776):

$$
\text { Convexity }=\frac{d^{2} P / d_{i}^{2}}{P}
$$

The price of a bond equals the present value of dicounted cash flows, so the price can easily be calculated at any given moment if the coupon rate, maturity and yield to maturity are known. The priceyield curve displays a set of prices for specific bonds (in terms of maturity and coupon rate) at a certain point in time.

The convex price-yield relation will differ with bonds that have different cash flows, and/or maturity and coupon rate. For example, the price-yield relation for bonds having shorter maturity period and a high coupon rate will be an almost straight line because the price does not change that much with the change in 
yield. Conversely, the price-yield relation for bonds with a longer maturity period and a low coupon rate will be a convex line. Between two bonds of the same duration but different convexity, it would be logical to choose the one with higher convexity, because it is bound to have a better price whether the yield is rising (the price of the bond will decrease less) or falling (the price of the bond will increase more).

Convexity measures the deviation of the priceyield curve from its linear approximation. For noncallable bonds convexity is always positive, meaning that the price-yield curve is located above the line which is indicator for modified duration and the tangent to the curve.

\section{Calculation of convexity}

Convexity is calculated in the following manner (Reilly and Brown, 2003, p. 777):

$$
\begin{aligned}
& \text { Convexity }=\frac{d^{2} P / d_{i}^{2}}{P}= \\
& =\frac{d^{2} P / d_{i}^{2}}{\text { Current value of chas flows }}
\end{aligned}
$$

$$
\frac{d^{2} P}{d i^{2}}=\frac{1}{(1+i)^{2}}\left[\sum_{t=1}^{n} \frac{C F_{t}}{(1+i)}\left(t^{2}+t\right)\right]
$$

Calculating the convexity (Reilly and Brown, 2003 , p. 777) of the $12 \% 3$-year bond with the yield to maturity of $9 \%$ per annum would be as follows:
Convexity varies for different sections of the price-yield curve, just as modified duration varies for different points on the price-yield curve because of the slope allternations. Maturity and coupon rate stay unchanged, and it is the yield to maturity rate (which changes) that indicates the section of the price-yield curve in question.

Convexity may also be calculated by the following formula (Fabozzi, 2007, p. 180):

$$
\text { Convexity }=\frac{P_{+}+P_{-}-2 P}{2 P(\Delta i)^{2}}
$$

Suppose that the current price of a 6.7\% 5-year bonds is 102.7509 , and that increase in yield by 10 basis points result in decline in the price to 102.3191, and that yield drop of 10 basis points result in bond price increase to 103.1849 (Fabozzi, 2005, pp. 215216). Effective convexity according to the formula (24) would be:

Convexity $=\frac{103.1849+102.3191-2 * 102.7509}{102.7509 *(0.001)^{2}}=21.41$

The effect of convexity on price is calculated in the following manner (Reilly and Brown, 2003, p. 778):

$$
\begin{aligned}
& \text { Change } \\
& \text { in price } \\
& \text { due to } \\
& \text { convexity }
\end{aligned}
$$

\begin{tabular}{cccccc}
\hline 1 & 2 & 3 & 4 & 5 & 6 \\
\hline Year & CF & PV 9\% & PV CF & $\mathrm{t}^{2}+\mathrm{t}$ & $4 * 5$ \\
\hline 1 & 120 & 0.9174 & 110.09 & 2 & 220.18 \\
\hline 2 & 120 & 0.8417 & 101.00 & 6 & 606.00 \\
\hline 3 & 120 & 0.7722 & 92.66 & 12 & 1111.92 \\
\hline 3 & 1000 & 0.7722 & 772.20 & 12 & 9266.40 \\
\hline & & $\mathrm{P}=1075.95$ & & 11204.50 \\
\hline
\end{tabular}

$$
\begin{gathered}
1 /(1+i)^{2}=1 /(09)^{2}=0.84 \\
11204.50 * 0.84=9411.78
\end{gathered}
$$
be:

In the previous example, the price change would

$1 / 2 * 102.7509 * 21.41 *(0.001) 2=0.0011$ 


\section{Attributes of convexity}

Attribute 1: As the required yield increases, convexity of a bond drops and vice versa, as the required yield drops, the convexity of a bond rises.

The slope of the tangent becomes less sharp as the required yield increases. A straighter tangent indicates a lower modified duration as the required yield increases. Conversely, the tangent becomes steeper with the decrease of the required yield, and the modified duration rises. This leads to the conclusion that convexity actually measures the rate of change of monetary duration of a bond as a result of the market yield change.

Atributte 2: For the given yield and maturity, the lower the coupon rate the higher the convexity of a bond.

Attribute 3: For the given yield and modified duration, the lower the coupon rate the lower the convexity. Zero-coupon bonds have the lowest convexity for the given modified duration.

Atributte 4: Convexity of a bond increases at an incremental rate with the increase in a bond duration. The implication hereof is that if an investor trades this bond for another with a duration twice as long, the convexity shall more than double.

Modified convexity assumes that the cash flow rejected by a bond does not change with the change of interest rates. Moreover, modified convexity is not a reliable indicator in the case of bonds with embedded option. In order to overcome these drawbacks, a concept of effective convexity has been developed.

\section{Effective convexity}

Effective convexity assumes that cash flow varies depending on the change in yield. It is calculated by the following formula (Reilly and Brown, 2003, p. 783):

$$
\text { Convexity }_{\text {eff }}=\frac{P_{+}+P_{-}-2 P}{P(\Delta i)^{2}}
$$

where $\mathrm{P}$ is - estimated bond price after fall of interest rates, $\mathrm{P}_{+}$- estimated bond price after rise of interest rates, $\mathrm{P}$ - current bond price, i.e. price before change of interest rates, and $\Delta \mathrm{i}$ - anticipated change in yield. So the formula is the same as for modified convexity. There is a difference, however. Namely, valuation models used for calculating bond prices affected by a change in yield must here take into account that cash flow varies with the change of interest rates, i.e. that in bonds with embedded option cash flows vary considerably depending on the level of interest rates.

\section{Convexity of a bond with a call option}

Suppose that the 6.25\% 5-year bond with current price 99.8030 is callable between 2nd and 5th year and that increase in yield by 10 basis points result in decline in the price to 99.4932 , and that yield drop of 10 basis points result in bond price increase to 100.1086 (Fabozzi, 2005, p. 215, p. 219). Effective convexity according to the formula (26) would be:

$$
\text { Convexity }=\frac{100.1086+99.4932-2 * 99.8030}{99.8030 *(0.001)^{2}}=-42.1
$$

Bonds without embedded option (noncallable) have positive convexity, because when yield drops, the bond price rises at an incremental rate. On the other hand, with bonds that have a call option, when the interest rates fall, the bond price rises at a decremental rate, up to the point where all changes halt. Such behaviour of the price-yield curve in the face of yield changes is called negative convexity and it is one of the risks accompanying a callable bond.

Starting from the yield $y^{\star}$ (Chart 1$)$, the rise in interest rates results in the drop of the value of the call option, for when interest rates exceed the coupon rate by large, the probability of the issuer resorting to his option right is small, so the option's value diminishes as well. In this case the price of the callable bond is similar to the price of the noncallable bond. In the opposite case, the drop of interest rate below $\mathrm{y}^{\star}$ increases the probability of the issuer using the right from the option and redeeming the bond, thus increasing the value of the option itself. As a result, the price of a callable bond differs from the price of a noncallable bond, where the increase in price of the callable bond is initially slower than the one of the noncallable bond, and then it stops.

\section{Convexity of a bond with a put option}

Suppose that the 5.75\% 5-year bond with the current price of 100.1089 is putable between 2nd and 5 th year and that 10 basis points increase in 
yield result in decline in the bond price to 99.8424 , while drop in yield by 10 basis points result in price increase to 100.3819 (Fabozzi, 2005, p. 215, p. 220). Effective convexity according to the formula (26) would be:

$$
\text { Convexity }=\frac{100.3819+99.8424-2 * 100.1089}{100.1089 *(0.001)^{2}}=65
$$

Effective convexity of a bond with a put option remains positive for all interest rate changes. However, the convexity of such a bond is reduced as the interest rates rise. This is due to the fact that the probability of using the put option is low when the market rates are lower than the coupon rate, so the price of such a bond changes in the same manner as the price of an ordinary bond, and vice versa. Since the price-yield curve must be quickly adjusted to this change, the convexity of the bond with a put option is large.

$$
\begin{aligned}
& \sum \text { (modified duration of every investment } * \text { value of } \\
& \text { every investment) } \\
& \text { Modified duration }=\frac{\text { value of a portfolio }}{\text { valu }} \\
& \Sigma \text { (convexity of every investment * value of every } \\
& \text { investment) } \\
& \text { Convexity }=\frac{\text { value of a portfolio }}{\text { valu }}
\end{aligned}
$$

\section{Duration and convexity}

Accordingly, there are two factors influencing the bond price changes in response to the change in yield: modified duration of a bond and its convexity. A relative influence of any of these factors on the change in price shall depend on the bond properties (maturity and coupon rate) and the amplitude of the yield change. Modified duration may be useful in determining the approximate percentage bond price change for a given change in yield, but the information is valid only for minor changes in yield. In case of major changes in yield and/or bonds with large modified convexity, the impact of convexity must also be considered, while otherwise the estimated price change would be overestimated or underestimated.

The price change due to duration of the $12 \%$ 18-years bond (Reilly and Brown, 2003, p. 779) with the yield to maturity of $8 \%$, price of 126.50 , modified duration of 8.38 , and the convexity of 107.70 would be equal to the modified duration multiplied by the change in yield and divided by 100 (formula 1.10), and the price change due to convexity would be equal to a half of the price multiplied by convexity and the square of the of yield change (formula 1.25). If the decline in yield is first 100, and then 300 basis points, we would get the following:

\section{Convexity of a portfolio}

Convexity of a portfoilio is acquired by first calculating the convexity of each bond in the portfolio and then calculating the weighted average convexity of all the bonds in a portfolio, where weights represent the share of the bond's value in the total value of the portfolio.

If the fall in interest rates is foreseen, bonds with greater convexity will generate greater income. In the same way, the loss incurred because of unforeseen increase in interest rates is smaller with a greater convexity bond. Hence, it is insignificant whether interest rates fall or rise, the convexity nonetheless enhances the performances of the portfolio. Subsequently, if the greater volatility of interest rates is predicted, the convexity of the portfolio should be improved.
A: Yield change: -100 basis points Change - duration: $-8.38 *(-100 / 100)=8.38 \%$

$8.38 \% * 126.50=10.60$

Change - convexity: $1 / 2 * 126.50 * 107.70 * 0.012=0.68$

The combined effect: $126.50+10.60+0.68=$

B: Yield change: -300 basis points

Change - duration: $-8.38+(-300 / 100)=25.14$

$25.14 \% * 31.80=126.50$

Change - convexity: $1 / 2 * 126.50 * 107.70 * 0.032=6.11$

The combined effect: $126.50+31.80+6.11=164.41$

This impact of convexity will be smaller if the change in yield is high but the convexity of the bond is low (due to the high coupon rates or short maturity), because the price-yield curve is almost a horizontal line in that case. Modified duration and convexity considered together provide the best approximation of the sensitivity of the bond price to the interest 
rates change. They have a disadvantage, however, of assuming the parallel shifts in yield curve.

With increase in duration, convexity grows at an incremental rate. The larger the share of convexity, the less precise the percentage price change provided by duration. This is most starkly visible with considerable changes in yield. Also, duration and convexity are used for bonds with low credit risk. They are not to be heavily relied upon when dealing with a higher credit risk bonds, because neither duration nor convexity are good indicators of the sensitivity of the bond price to the interest rate change.

In 1995 Barber J.R. arrived at the approximation of the bond price sensitivity based on duration and convexity. The bond price equals:

$$
P=\sum_{t=1}^{n} \frac{C F_{t}}{(1+y)^{t}}
$$

The expanded Taylor's line would be:

$$
\Delta P / P_{0}=-D \Delta y+1 / 2\left(C-D^{2}\right)(\Delta y)^{2}
$$

where $\mathrm{D}$ and $\mathrm{C}$ represent modified duration and convexity respectively, and $\Delta y$ is the change in yield.

The previous formula yields erroneous results for major changes in yield. Far better results are obtained by using a logarithmic approximation:

$$
\Delta P / P_{0}=\exp \left[-D \Delta y+1 / 2\left(C-D^{2}\right)(\Delta y)^{2}\right]-1
$$

The logarithmic approximation provides more accurate results in the case of large changes in yield. The formula (27) provides actual bond prices. The other two formulas (28 and 1.29) give approximate bond prices. The Barber study revealed that with lesser interest rate disturbances (up to 100 base points), both approximative formulas give results similar to the one from the first formula. However, with greater changes in interest rates, e.g. 300 base points, the logarithmic approximation of price is more precise than the conventional approximation models.

\section{RESUME}

Not only is the overall cash flow that bond rejects important for investment decision, but also the period in which it happens. Maturity of the bond gives information only on the date of the final payment, but not on the size and date of coupon payments prior to the last payment of coupon and principal. The longer the period to maturity, the higher the coupon rate and yield to maturity, the more important coupon payments are. Maturity of the bond, therefore, is not an adequate indicator of the time required to pay off investment in bonds. Due to this, the concept of bond duration has been developed.

Duration is a measure of interest rate risk of bonds and it is used to determine the average period of maturity of the bond. Duration measures price sensitivity of bonds or bond portfolios on the changes in interest rates. There are different types of duration.

Macaulay and modified duration give a good approximation of the interest sensitivity of bonds butonly for small changes in yield, and, unfortunately, cannot be used in the case of major changes in yield, and in the case of bonds with embedded option. Hereof, effective duration has been developed. The advantage of this concept is that it allows duration to be longer than maturity, and to be negative, so it can be used for bonds with an embedded option while it allows the bond cash flow to change due to changes in yield. However, as the effective duration involves the use of interest models, the problem arises when measuring the interest sensitivity of assets for which it is not possible to give precise predictions for the price based on the change in yields. In order to provide an assessment of the sensitivity of bond in these cases, the concept of empirical duration has been developed.

Duration is the approximate percentage change in bond price for a change in interest rates. However, the information is relevant only for small changes in yield. In the case of a major change in yield, estimates based only on modified duration underestimated price increase caused by the decrease of yield and overestimate the drop in price due to the increase in yields. This misperception arises because the modified duration is the linear estimation of non-linear price-yield relation. Thus, the price-yield curve is not straight but curved line. Convexity measures deviation of the price-yield curve from its linear approximation. Like duration, convexity also suffers from certain drawbacks. Modified convexity assumes that the cash flow of a bond does not change with a change in interest rates, so it is inadequate for the bonds with embedded option. To overcome these deficiencies, effective convexity has been developed. Effective convexity assumes that the cash flow changes with the change in yield. 
Two factors determine the bond price changes due to changes in interest rates: the modified duration of the bond and its convexity. The relative significance of these factors depends on the characteristics of a bond (maturity, coupon rate) and the size of the interest rate change. The best approximation of the sensitivity of a bond to interest rate changes is obtained by a combination of modified duration and convexity. However, it should be noted that the approximation of bond price changes due to changes in interest rates is based on the assumption that the yield curve shifts are parallel.

\section{REFERENCES}

Barber, J.R. (1995). A note on approximating bond price sensitivity using duration and convexity. The Journal of Fixed Income, 4(4), 95-98. doi: 10.3905/jfi.1995.408123.

Choudhry, M. (2005). Fixed-income securities and derivatives handbook: Analysis and valuation. Princeton, N.J: Bloomberg Press.

Fabozzi, F.J. (1996). Measuring and controlling interest rate risk. New Hope, PA: Frank J. Fabozzi Associates.
Fabozzi, F.J. (2000). Bond markets, analysis and strategies. Upper Saddle River, N.J: Prentice Hall.

Fabozzi, F.J., \& Mann, S.V. (2005). The handbook of fixed income securities. New York: McGraw-Hill.

Fabozzi, F.J. (2007). Fixed income analysis. Hoboken, N.J: Wiley.

Hull, J. (2009). Options, futures and other derivatives. Upper Saddle River, N.J: Prentice Hall.

La Grandville, Olivier de. (2001). Bond pricing and portfolio analysis: Protecting investors in the long run. Cambridge, MA: MIT Press.

Mishkin, F.S., \& Eakins, S.G. (2005). Financial markets and institutions. Boston: Addison Wesley.

Reilly, F.K., \& Brown, K.C. (2003). Investment analysis and portfolio management. Mason, OH: South-Western/ Thomson Learning.

Steiner, R. (1998). Mastering financial calculations: A step by step guide to the mathematics of financial market instruments. London: Financial Times.

Šoškić, D.B., \& Živković, B.R. (2006). Finansijska tržišta $i$ institucije. Beograd: Centar za izdavačku delatnost Ekonomskog fakulteta. (in Serbian).

\section{TRAJANJE I KONVEKSNOST OBVEZNICA}

\section{Rezime:}

Veliki uticaj koji promene kamatnih stopa imaju na uspešnost poslovanja, činjenica da su svi tržišni učesnici, više ili manje, izloženi kamatnom riziku, kao i velika volatilnost kamatnih stopa poslednjih godina, čine kamatni rizik jednim od najznačajnijih rizika.

Kamatni rizik je nemoguće u potpunosti eliminisati, ali ga je poželjno svesti na najmanju moguću meru. Kako bi se efikasno upravljalo kamatnim rizikom najpre se mora prepoznati i izmeriti izloženost ovoj vrsti rizika. Ovaj rad ima za cilj da ukaže na dve metode merenja kamatnog rizika - na trajanje i konveksnost.

Koncept trajanja je dobar pokazatelj promene cene obveznice ali samo za male promene prinosa (kamatnih stopa). U slučaju većih promena, trajanje daje precenjenu/potcenjenu aproksimaciju promenu cene obveznice, jer odnos cena obveznice - prinos nije linearan. Zbog toga se prilikom merenja kamatnog rizika u obzir mora uzeti i konveksnost obveznice. Modifikovano trajanje i konveksnost uzeti zajedno daju najbolju aproksimaciju osetljivosti cene obveznice na promenu kamatnih stopa.

\author{
Ključne reči: \\ Mekulijevo, \\ modifikovano, \\ efektivno, \\ empirijsko novčano trajanje, \\ trajanje portfolia, \\ modifikovana i efektivna kon- \\ veksnost, \\ konveksnost portfolia.
}

Received: October 29th, 2013. Correction: November 21st, 2013. Accepted: November 25th, 2013. 